\title{
ПРЕПАРАТИ В ФОРМІ ПЕЛЕТ, СИСТЕМАТИЗАЦІЯ ІНФОРМАЦІЇ ЩОДО МЕТОДІВ ВИРОБНИЦТВА, ДОСЛІДЖЕННЯ МІКРОСТРУКТУРИ ТА ВЛАСТИВОСТЕЙ ПЕЛЕТ ОМЕПРАЗОЛУ
}

\section{Єрхова Анна', Катинська Марина ${ }^{2}$}

${ }^{1}$ Студентка магістратури, Інституту біомедичних технологій, «Відкритого міжнародного університету розвитку людини «Україна» Київ, Україна.

${ }^{2}$ Кафедра фармації Інституту біомедичних технологій, «Відкритого міжнародного університету розвитку людини «Україна» Київ, Україна.

Анотація. У статті наведений огляд фармацевтичних препаратів у формі пелет, систематизачія інформації щуодо методів виробництва, дослідження мікроструктури та властивостей пелет омепразолу. Основною метою проведеного дослідження є узагальнення випадків, коли використання такої форми як пелети є найбільш обтрунтованим, провести огляд лікарських засобів в Україні, щуо містять пелети, порівняти пелети від українських виробників (було вирішено взяти пелети від корпораиії Артеріум та Фармак) з закордонними (в якості закордонних виробників, було вирішено взяти виробників Tеvа та CheтоIberica), узагальнити сучасні методи виробництва пелет, дослідити доступні пелети омепразолу від різних виробників, порівняти їх властивості та обгрунтувати метод, який був використаний у виробництві. 3 метою порівняння властивостей пелет від різних виробників було вирішено дослідити морфологію, щільність, діаметр, середню масу пелет омепразолу. Дослідити та порівняти стійкості кишковорозчинних пелет омепразолу різних виробників до рідкого середовища з різними показниками рН. На підставі отриманих експериментальних даних пояснити можливу причину відмінностей у властивостях досліджуваних пелет. Методика проведення включала дослідження морфології, щільності, діаметру, середньої маси. У роботі було використано мікроскопію та гравіметричний аналіз. Для дослідження стійкості кишковорозчинних пелет до рідкого середовища з різними показниками рН було використано метод, щзо досліджує приріст вмісту вологи (після експозиції у розчинах, що імітують можливий рівень рН шлунку людини) та втрати в масі після висушування або швидкість розпадання пелет. Об'єктом дослідження обрано пелети омепразолу від виробників корпораиії Артеріум (Київмедрепарат), Фармак, ChетоIberica (CI) та Tеvа. У статті представлено результати експерименту, який засвідчи, щчо всі пелети мають резервуарну систему, пелети виробників ChетоIberica, Артеріум та Теvа були виготовлені методом нашарування для введення активного фармацевтичного інгредієнту, а пелети від виробника Фармак були виготовлені з використанням методу прямої пелетизації. Також при дослідженні кишковорозчинних властивостей пелет були розраховані показники по вологопоглинанню та втрати в масі після висушування. Виходячи зі складу допоміжних речовин, який представлений в інструкиії до препаратів, можна припустити, щзо у ролі функціонального полімеру при виробництві плівкових оболонок у ChemoIberica, Teva та Фармак иим полімером виступає метакрилатний сополімер, а у виробника Артеріум гіпромелоза фталат. Обидва полімери застосовуються у пероральній лікарській формі, як матеріал для ентерального/кишковорозчинного покриття для таблеток, пелет або гранул. Результати проведеного дослідження можуть бути корисними для подальшого удосконалення формул виробництва препаратів у формі пелет.

Ключові слова: кишковорозчинні пелети, метод нашарування активного фармацевтичного інгредієнту, омепразол, пряма пелетизація.

Cite as: Pharmaceutical preparations in the form of pellets, systematization of information on production methods, study of microstructure and properties of omeprazole pellets 
Вступ Для національної науки та фармацевтичної галузі пріорітетнним завданням $\epsilon$ створення та забезпечення громадян України оригінальними високоефективними генеричними лікарськими засобами Але, на сьогодні, Україна поступається розвинутим країнам у використанні високотехнологічних методів виробництва лікарських засобів. Один із напрямків - це розробка та виробництво пероральних лікарських форм як пелети.

Пелети належать до мультипартикулярних лікарських форм та мають ряд переваг у порівнянні з монопартикулярними лікарськими формами, що дозволяє розглядати пелети, як перспективні пероральні системи доставки активного фармацевтичного інгредієнту (Majeed, Al-Shaheen, Al-Zidan, \& Mahmood, 2020). Пероральні лікарські форми є найпоширенішими, адже пероральний шлях введення лікарських форм є неінвазивним. (Нековаль \& Казанюк, 2018)

Станом на цей час, в Україні одним з найпоширеніших лікарських засобів (ЛЗ) у формі мікрогранул $\epsilon$ кишковорозчинні пелети омепрозолу, що доступні у вигляді капсул. Жоден 3 українських виробників не виробляє самостійно кишковорозчинні пелети (закуповують вже готові пелети), хоча на ринку України доступні лікарські засоби як українського. так i закордонного виробництва.

Тверді лікарські форми (ЛФ) поділяють за принципом розподілення активного фармацевтичного інгредієнту (АФІ) на носії на монопартикулярні та мультипартикулярні. Монопартикулярні лікарські форми простіші у виробництві, ніж мультипартикулярні ЛФ, але останні нівелюють ризик небажаного вивільнення повної дози АФІ, якщо ЛФ має пролонгований або модифікований профіль вивільнення АФІ.

Прикладами мультипартикулярних ЛФ можуть слугувати таблетки та капсули, які містять пелети з функціональним покриттям та багатошаровим покриттям.

Пероральні системи доставки АФІ включають в себе системи с запрограмованим вивільненням препарату, яке регулюється функціональним покриттям.
За морфологічними ознаками, як мультипартикулярні так і монопартикулярні ЛФ можна поділити на резервуарні та матриксні. Резервуарні системи включать в себе АФІ, що міститься безпосередньо в ядрі, яке покрите водонерозчиними плівками, які зазвичай містять полімери (наприклад: сополімери метакрилата, полівінілацетат, етилцелюлозу, гіпромелози фталат та інші). Матриксні системи містять матриксностворюючу допоміжну речовину. У якості матриксоутворювача можуть бути використані: розчинні полімери такі, як гідроксіпропілцелюлоза, гідроксипропілметилцелюлоза, поліетиленоксид; нерозчинні полімери - полівінілацетат, етилцелюлоза, целюлози ацетат; ліпіди, включи гліцериди жирних кислот, парафіни та ін. При виробництві матриксних систем зазвичай використовують вологу або суху грануляцію, пряме таблетування. Ці методи виробництва у комплексі 3 використанням різних полімерів дозволяють зберегти цілісність ЛФ протягом часу вивільнення АФІ. Такі системи володіють майже лінійний профіль вивільнення АФІ. (Демчук, Грошовий, Найда \& Коваль, 2019)

Як матрична, так і резервуарна системи є придатними для виробництва кишковорозчинних пелет омепразолу. Але виробництво матричних пелет методом прямої пелетизації зі включенням $\mathrm{pH}$-розчинного полімеру до складу пелет не раціонально, зважаючи на кілька причин: по перше, матриксна система буде потребувати більшої кількості рН-розчинного полімеру, а по-друге, очікується, що кінетика вивільнення з матриксної системи буде повільнішою, ніж з резервуарної. Тому застосування резервуарної системи виглядає більш оптимальним.

Для реалізації резервуарної системи рН-розчинний полімер у вигляді оболонки має бути нанесений на ядра, що містять омепразол. Введення омепразолу до складу ядер може бути реалізовано кількома методами. Найбільш розповсюдженні - екструзія-сферонізація, агрегація-сферонізація та нашарування омепразолу на інертні ядра (Mohylyuk, Styliar, Novykov, Pikett, \& Dattani, 2019).Тобто, для отримання ядер з омепразолом, омепразол 
може бути змішаний з допоміжними речовинами, суміш зволожена, екструдована, сферонізована і потім отримані ядра висушені. Або, омепразол може бути змішаний 3 допоміжними речовинами, суміш зволожена, піддана грануляції з отриманням округлих гранул та висушених (Mishra, Paldewar, \& Nandgude, 2020). Альтернативно, на інертні ядра, як то цукрові сфери або сфери 3 мікрокристалічної целюлози, може бути нанесений розчин або суспензія омепразолу разом з розчиненим зв'язуючим полімером, що забезпечує адгезію омепразолу до ядер (Al-Hashimi, Begg, Alany, Hassanin, \& Elshaer, 2018). Аби створити ефективний та безпечний препарат, у процесі розробки лікарських засобів необхідно враховувати всі ключові моменти, починаючи з умов виробничого процесу, вибору складу та розробки індивідуальної рецептури завершуючи можливістю багатократного відтворення. (Тригубчак О.В.,Гуреєва С.М., Юр'єва О.О., Лисенко О.С., \& Гой А.М., 2018)

Методи. Для проведення експеримента були використані капсули (1 капсула містить 20 мг омепразолу) 3 кишковорозчинними пелетами омепразолу. Також були використані: оцтова кислота, натрій ацетат, хлорид натрію, хлоридна кислота та вода очищена. Якість усіх використаних реактивів відповідала хіміко-аналітичним вимогам фізико-хімічної лабораторії матеріально-технічної бази (ПрАТ «ІНДАР»).

Метод дослідження приросту вмісту вологи та втрати в масі після висушування використовувався для визначення стійкості кишковорозчинних пелет до середовищ 3 різними показниками $\mathrm{pH}$. Для виконання цього методу на аналітичних вагах було відміряно по 300 мг пелет, (попередньо звільнивши зразок від пошкоджених або поламаних пелет та пилу). Після цього були приготовлені ацетатний буферний розчин (pH 3,$5 ; 4,5)$ та розчин $\mathrm{HCl}(\mathrm{pH}$ $1,2 ; 2,5 ; 3,5)$. Далі пелети були розмішені по кошиках приладу для дослідження 3 розчинення (ApparatusI - ERWEKA-DT 700, Hiмеччина). Експозиція у кошиках (швидкість обертання 100 об/хв) тривала 2 години у середовищі зазначених розчинів при температуpi $37 \pm 1^{\circ} \mathrm{C}$. Після цього, пелети були зважені, висушені при $105^{\circ} \mathrm{C}$ до постійної маси (приблизно 12 годин) та повторно зважені. Експеримент повторювали тричі для кожного типу пелет та кожного середовища.

Втрату в масі після висушування визначали за формулою:

$$
\mathrm{WL}=\underline{\mathrm{m}}_{0} \frac{-\mathrm{m}_{2}}{\mathrm{~m}_{1}} \times 100
$$

Де:

$\mathrm{m}_{0}$ - маса до експозиції у кислому середовищі, мг;

$\mathrm{m}_{2}$ - маса після висушування.

$\mathrm{m}_{1}$ - маса після експозиції у кислому середовищі, мг;

Приріст вмісту вологи визначали за формулою:

$$
\mathrm{WU}=\frac{\underline{\mathrm{m}}_{1}-\underline{\mathrm{m}}_{0}}{\mathrm{~m}_{0}} \times 100
$$

Де:

$\mathrm{m}_{1}$ - маса після експозиції у кислому середовищі, мг;

$\mathrm{m}_{0}$ - маса до експозиції у кислому середовищі, мг.

Для визначення мікроструктури пелет було проведено мікроскопічне дослідження поперечного перерізу покритих пелет. Для підготовки зразків_пелети розміщували на скляній поверхні розплавлену полімерну суміш (поліетилен-вінілацетат $(40 \%)$, вінілацетат (10\%), терпенфенольна смола (30\%) і парафін $(20 \%)$ за температури $\approx 70^{\circ} \mathrm{C}$. Зріз зафіксованих пелет виконували з використанням скальпелю (Mohylyuk, Patel, Murnane, Richardson, \& Liu, 2018).

Для визначення діаметру застосовувалась мікроскопія пелет, після їх зважування. Для кожної пелети діаметр замірявся декілька разів, по 2 рази з різних боків. Після, для кожної з мікрогранул рахувався середній показник.

Для визначення щільності пелет використовували тільки пелети, форма яких була близькою до сферичної. За допомогою мікроскопа були визначені найбільший та найменший діаметр пелети та розрахований середній діаметр. Після цього, швидкість осідання пелети в циліндрі з очищеною водою 
(висота стовпа води 32 см) визначалась за допомогою секундоміру. Щільність розраховували за законом Стокса по формулі:

Де:

$$
\rho_{\mathrm{p}}=\underline{\mathrm{v}}_{\mathrm{s}} \frac{\times 18 \eta}{\mathrm{D}^{2} \times \mathrm{g}}+\rho_{\mathrm{f}}
$$

$v_{s}=l / t-$ швидкість осадження пелети (м/с);

$l$ - дистанція (м)

$t$ - час осідання пелети (c)

$g$ - прискорення вільного падіння $\left(\mathrm{м} / \mathrm{c}^{2}\right)$;

$\rho_{\mathrm{p}}$ - щільність пелети (кг / м 3 );

$\rho_{\mathrm{f}}$ - щільність води за кімнатної температури (кг/ $\left.\mathrm{M}^{3}\right)$.

Для визначення щільності, 90 пелет кожного виробника було протестовано.

Середня маса визначалась двома методами. За першим методом, на підставі виміряного середнього діаметра пелети розраховувався іiі об'єм, а потім об'єм пелети множився на щільність цієї пелети для отримання іiі маси. За результатами маси окремих пелет розраховувалась середня маса пелет. Другий метод полягав у зважуванні на вагах пелет по 30 штук.

Результати/Кишковорозчинні пелети омепразолу виробництва Chemolberica, Teva, Apтеріум та Фармак були досліджені методом мікроскопії поперечного зрізу пелет (Рис. 2.42.15).У листопаді 2020 року попередні результати етапу мікроскопії зрізів пелет та таблиці 3 фізичними показниками, вологопоглинання та втраті в масі після висушування були опубліковані на конференції «NEW CHALLENGES AND THREATS IN SCIENCE» у Ванкувері, Канаді.

У ході мікроскопії пелет було отримано результати, показані на стор. 46.

Зі зрізів можна зробити висновок, що пелети Chemo Iberica, Teva та КМП були виготовленні
3 використанням методу нашаровування функціональних оболонок на ядра. Функціональні полімери, що були використані для цього - це метакрилатний сополімер (ChemoIberica, Teva та Фармак) та гіпромелози фталат (КМП), згідно до складу, вказаного у інструкціях до медичного застосування цих ЛЗ.

Мікроскопічне дослідження дозволило з'ясувати, що всі пелети - виробництва ChemoIberica, Teva, Київмедпрепарат КМП та Фармак мають ще один шар та ядро, що свідчить про застосування методу нашарування для введення АФІ до складу пелет. На відміну від згаданих пелет, під час дослідження поперечних зрізів мікрогранул виробництва Фармак, чітких контурів додаткового шару та ядра виявлено не було. Це може свідчити про те, що АФІ до пелет був введений методом прямої пелетизації.

При визначені фізичних властивостей пелет були з'ясовані показники - діаметру, об'єму, середньої маси та щільності. За діаметром пелети різних виробників у порядку зменшення розташовувались у наступній послідовності -Teva (1499 мкм), Фармак (1488 мкм), Chemolberica (1379 мкм), Артеріум (1127 мкм). За середньою масою пелет, у порядку зменшення розташовувались у наступній послідовності - Фармак (2,257 мг), Chemolberica (1,96 мг),Teva (1,541 мг), КМП (0,97). За показником щільності у порядку зменшення: Артеріум (1,18г/мл), ChemoIberica (1,16г/мл), Teva (1,13г/мл), Фармак (1,06 г/мл). За об'ємом у порядку зменшення: Teva $\left(1,781 \mathrm{~mm}^{3}\right)$, Фармак $\left(1,381 \mathrm{Mm}^{3}\right)$,Chemolberica $\left(1,378 \mathrm{Mm}^{3}\right)$,Київмедпрепарат $\left(0,752 \mathrm{Mm}^{3}\right)$.

Всі дані представлені в таблиці 1.

При дослідженні вологопоглинання та втрати в масі після двогодинної експозиції в

Табл 1. Діаметр, об’єм, щільність та маса пелет різних виробників (n=90)

\begin{tabular}{|l|l|l|l|l|}
\hline \multicolumn{1}{|c|}{ Виробник } & \multicolumn{1}{c|}{ Діаметр } & \multicolumn{1}{c|}{ Об'єм } & \multicolumn{1}{c|}{ Сер.маса } & Щільність \\
\hline & мкм & Mм $^{3}$ & мГ & Г/мл \\
\hline ChemoIberica & 1379,343 & 1.378 & 1,96 & 1,16278 \\
\hline KMП & 1127,482 & 0.752 & 0,97 & 1,18367 \\
\hline Teva & 1498,8 & 1.781 & 1,541 & 1,13266 \\
\hline Фармак & 1488,253 & 1,3807 & 2,257 & 1,058 \\
\hline
\end{tabular}



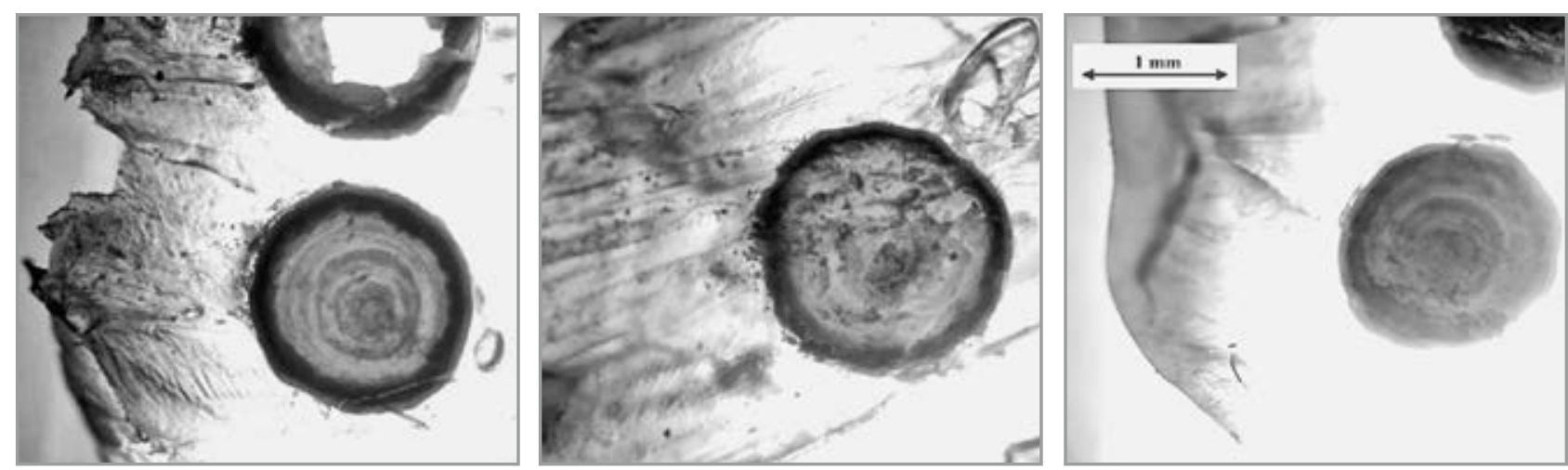

Рис. 1, 2, 3. Зрізи пелет виробника Chemo Iberica
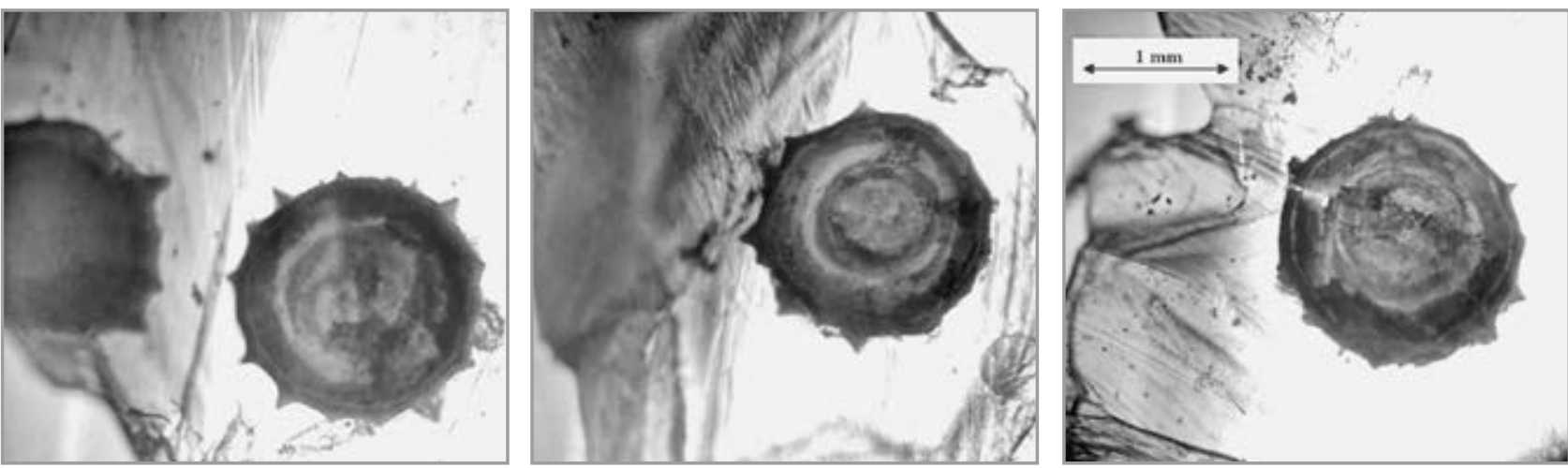

Рис. 4, 5, 6. Зрізи пелет виробника Tеva
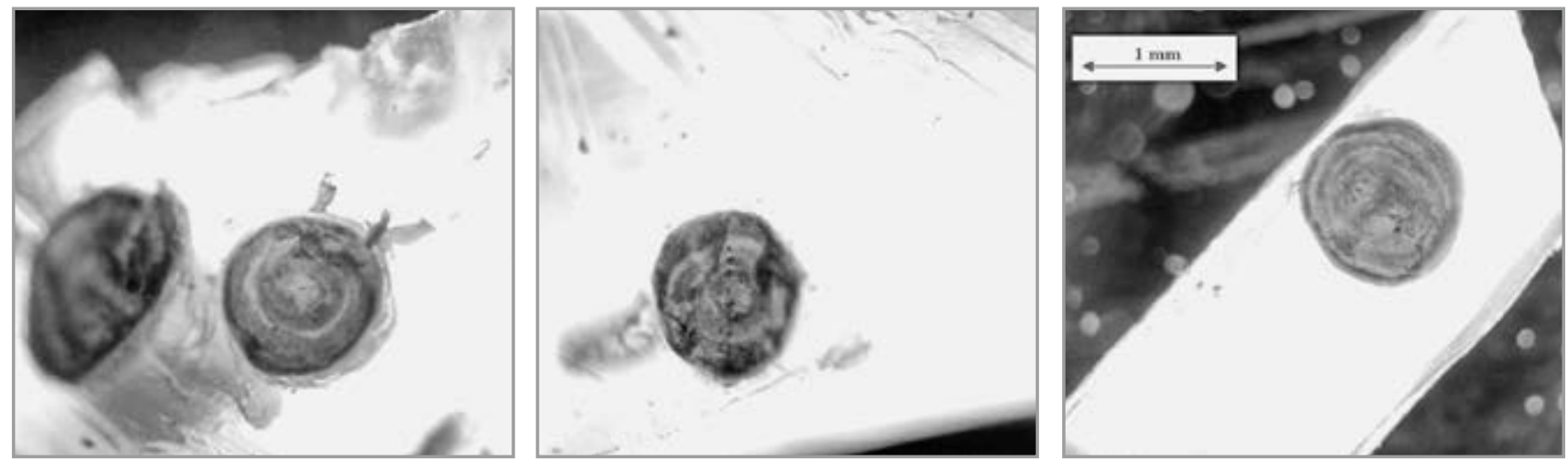

Рис. 7, 8, 9. Зрізи пелет виробника КМП
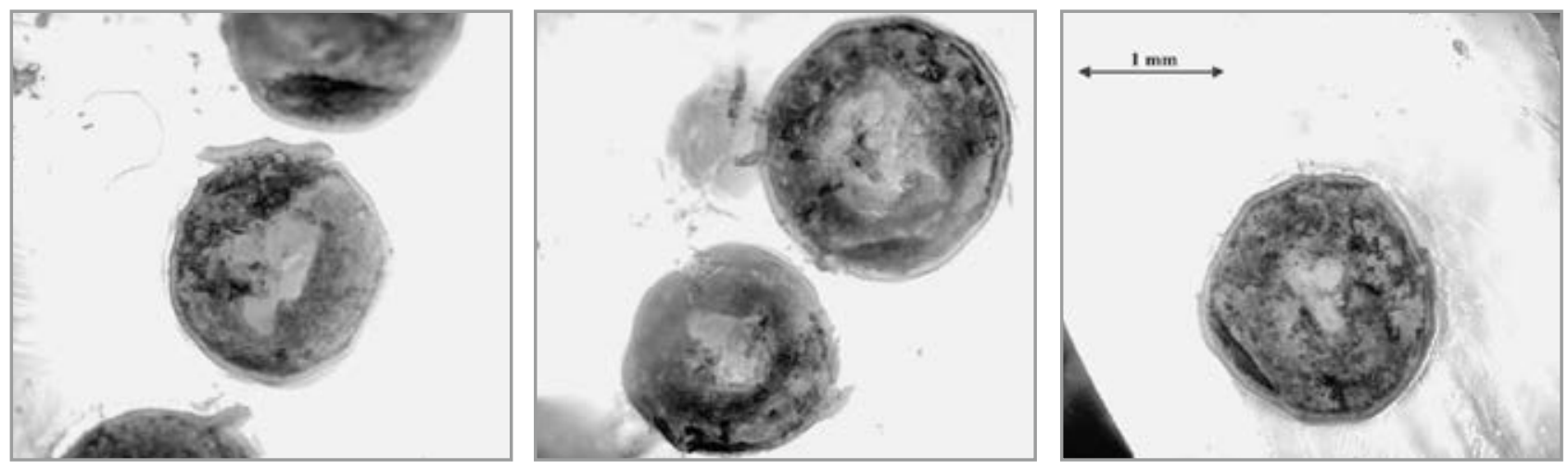

Рис. 10, 11, 12. Зрізи пелет виробника Фармак 
кислому середовищі пелети проявили різну поведінку (Таблиця 2.). Під час тестування, втрата пелет в масі пов'язана 3 негативними значеннями вологопоглинання.

Омепразол нестійкий в кислому середовищі, тому вологопоглинання у діапазоні $\mathrm{pH}$, що зображує можливу різноманітну кислотність шлунку людини, вказує на стабільність омепразолу в процесі проминання через шлунок пелетів. Від показника $\mathrm{pH}$ та від складу середовища залежало вологопоглинання. Про передчасне вивільнення омепразолу свідчить втрата в масі в процесі двогодинної експозиції в кислому середовищі. Втрата в масі залежала, як і від показників $\mathrm{pH}$, так і від середовища, аналогічно до вологопоглинання.

Вологопоглинання пелет від виробника Teva зменшувалося зі збільшенням $\mathrm{pH}$ у розчинах хлоридної кислоти від $38.2 \%$ до $17.9 \%$ та збільшувалось зі збільшенням $\mathrm{pH}$ у ацетатному буферному розчині від $25.2 \%$ до $36.7 \%$.

Вологопоглинання пелет виробництва Chemolberica зменшувалося зі збільшенням $\mathrm{pH}$ у розчинах хлоридної кислоти від $25.2 \%$ до $16.9 \%$ та збільшувалось збільшенням рН у ацетатному буферному розчині від $28.9 \%$ до $48 \%$.

Вологопоглинання пелет виробництва Артеріум/КМП зменшувалося зі збільшенням $\mathrm{pH}$ у розчинах хлоридної кислоти від $25.9 \%$ до $2.8 \%$, та збільшувалось збільшенням $\mathrm{pH}$ у ацетатному буферному розчині від $15 \%$ до $17.5 \%$.

Вологопоглинання пелет виробництва Фармак зменшувалося зі збільшенням $\mathrm{pH}$ у розчинах соляної кислоти від $48.3 \%$ до $-3 \%$ зменшувалась зі збільшенням $\mathrm{pH}$ ацетатному буферному розчині від $17.9 \%$ до $-8.6 \%$.

Втрата в масі пелет виробництва Teva та Chemolbericay розчинах HClта у ацетатному буферному розчин у діапазоні $\mathrm{pH}$ 1,2-4,5 не перевищувала $7 \%$.

Втрата в масі пелет виробництва Артеріум/ КМПу розчинахНCl(pH 1,2-3,5) збільшувалась $з$ 20,3\% до 25,5\% та у ацетатному буферному розчин становила $29.3 \%$ та $27.8 \%$ при pH 3.5 та 4.5, відповідно.

Втрата в масі пелет виробництва Фармакв розчинах $\mathrm{HCl}(\mathrm{pH}$ 1,2-3,5) збільшилась від 9,8\% до 42,5\%та у ацетатному буферному роз-

Табл 2. Дослідження вологопоглинання та втрати в масі після двогодинної експозиції в кислому середовищі.

\begin{tabular}{|c|c|c|c|c|c|c|c|c|c|c|}
\hline & \multirow{2}{*}{\multicolumn{2}{|c|}{$\begin{array}{c}\text { Середовище } \\
\text { та рН } \\
\end{array}$}} & \multicolumn{2}{|c|}{ Teva } & \multicolumn{2}{|c|}{ ChemoIberica } & \multicolumn{2}{|c|}{ Артеріум/КМП } & \multicolumn{2}{|c|}{ Фармак } \\
\hline & & & Av. & S.D. & Av. & S.D. & Av. & S.D. & Av. & S.D. \\
\hline \multirow{5}{*}{ 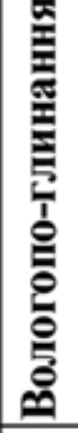 } & \multirow{3}{*}{$\begin{array}{l}\text { Розчин } \\
\text { НСІ }\end{array}$} & 1.2 & 38.2 & 4.0 & 25.2 & 4.7 & 25.9 & 6.7 & 48.3 & 9.5 \\
\hline & & 2.5 & 20.8 & 0.8 & 21.4 & 3.1 & 6.8 & 1.7 & 17.2 & 0.5 \\
\hline & & 3.5 & 17.9 & 1.4 & 16.9 & 1.2 & 2.8 & 3.7 & -3.0 & 4.2 \\
\hline & \multirow{2}{*}{\begin{tabular}{|l} 
Ацетат- \\
ний \\
буфер \\
\end{tabular}} & 3.5 & 25.2 & 0.9 & 28.9 & 2.1 & 15.0 & 4.0 & 17.9 & 1.4 \\
\hline & & 4.5 & 36.7 & 4.9 & 48.0 & 5.3 & 17.5 & 3.7 & -8.6 & 4.7 \\
\hline \multirow{5}{*}{ 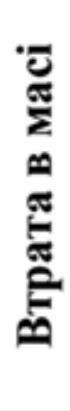 } & \multirow{3}{*}{$\begin{array}{l}\text { Розчин } \\
\text { НСl }\end{array}$} & 1.2 & 4.6 & 1.5 & 2.6 & 1.7 & 20.3 & 2.9 & 9.8 & 0.7 \\
\hline & & 2.5 & 4.8 & 3.4 & 5.2 & 2.0 & 22.2 & 0.5 & 13.9 & 2.3 \\
\hline & & 3.5 & 4.3 & 0.3 & 3.6 & 2.6 & 25.5 & 1.6 & 42.5 & 0.2 \\
\hline & \multirow{2}{*}{$\begin{array}{l}\text { Ацетат- } \\
\text { ний } \\
\text { буфер }\end{array}$} & 3.5 & 6.3 & 3.5 & 5.9 & 0.1 & 29.3 & 0.7 & 18.1 & 0.2 \\
\hline & & 4.5 & 4.3 & 0.9 & 4.1 & 0.4 & 27.8 & 0.9 & 35.5 & 4.2 \\
\hline
\end{tabular}


чин становила $18,1 \%$ до $35,5 \%$ при $\mathrm{pH} 3.5$ та 4.5, відповідно.

Обговорення та висновки. Резервуарну систему пелет від всіх виробників було визначено відповідно до їх складу та мікроскопії. На поверхні пелет присутня тонка полімерна кишковорозчинна оболонка (попередньо було з'ясовано стійкість пелет до середовища з різним $\mathrm{pH}$, яке може бути у шлунку).

У пелетах від Chemolberica, Teva, Київмедпрепарата АФІ було ведено методом нашарування. При виготовлені пелет від виробника Фармак був застосований метод прямої пелетизації для введення АФІ.

Діаметр, об'єм, середня маса та щільність у кожного виробника були визначенні на етапі дослідження фізичних властивостей пелет.

Показники по вологопоглинанню та втрати в масі були розраховані при дослідженні кишковорозчинних властивостей пелет, які пока- зують, що під час 2 годинної експозиції, яка мала на меті імітувати шлунок та його можливий $\mathrm{pH}$, який може бути вище за позначку 3,5 , пелети від виробників Фармак та Київмедпрепарат втратили більше 25\% від початкового дозування. Такі експериментальні умови розходяться 3 фармакопейними (2 години експозиції у розчині соляної кислоти з показником $\mathrm{pH}$ 1.2), але представляють можливі рівні $\mathrm{pH}$ у шлунку людини.

Було з'ясовано що у виробництві були використані 2 полімери - метакрилатний сополімер (Chemolberica, Teva та Фармак), та гіпромелози фталат (Київмедпрепарат (КМП)).

У виробництві пелет омепразолу був використаний метод нашарування функціональних оболонок на ядро.

Конфлікт інтересів - відсутній.

Фінансування - дана стаття не отримувала зовнішнього фінансування.

\section{СПИСОК ЛІТЕРАТУРИ}

Al-Hashimi, N., Begg, N., Alany, R. G., Hassanin, H., \& Elshaer, A. (2018). Oral modified release multiple-unit particulate systems: compressed pellets, microparticles and nanoparticles. Pharmaceutics, 10(4), 176. DOI: 10.3390/ pharmaceutics 10040176

Majeed, S. M., Al-Shaheen, M. K., Al-Zidan, R. N., \& Mahmood, S. M. (2020). Multiple Unite Pellet Systems (MUPS) as Drug Delivery model. Journal of Drug Delivery and Therapeutics, 10(6), 231-235. DOI: 10.22270/jddt.v10i6.4389

Mishra, R. V., Paldewar, S. G., \& Nandgude, T. D. (2020). An outline of variables in pelletization by extrusion and spheronization. International Journal of Applied Pharmaceutics, 39-44. DOI: 10.22159/ijap.2020v12i4.37277

Mohylyuk, V., Styliari, I. D., Novykov, D., Pikett, R., \& Dattani, R. (2019). Assessment of the effect of Cellets' particle size on the flow in a Wurster fluid-bed coater via powder rheology. Journal of Drug Delivery Science and Technology, 54 , 101320. DOI: 10.1016/j.jddst.2019.101320

Singh, I., Devi, G., Barik, B. R., Sharma, A., \& Kaur, L. (2020). Mucoadhesive Pellets for Drug Delivery Applications: A Critical Review. Reviews of Adhesion and Adhesives, 8(2), 153-167. DOI: 10.7569/RAA.2020.097305

V. Mohylyuk, V., Patel, K., Murnane, D., Richardson, C., Liu, F. (2018, November). Investigation into the internal structure of coated microparticles to support formulation and coating process development. AAPS PharmSci 360 , Washington, DC, United States.

Демчук М.Б., Грошовий Т.А., Найда Ю.В., \& Коваль В.М. (2019) Сучасний стан створення, виробництва та дослідження таблетованих лікарських препаратів. Фармацевтичний часопис, 2, 103-111. DOI: 10.11603/23120967.2019.2.10197

Нековаль, І.В., \& Казанюк Т.В. (2018) Фармакологія. Київ:Медицина

Представлення результатів експериментальної роботи з огляду фармацевтичних препаратів в формі пелет, систематизація інформації щодо методів виробництва, дослідження мікроструктури та властивостей пелет омепразолу: матеріали XI International Scientific and Practical Conference (16 - 17, November 2020, Vancouver), 87-88.

Тригубчак О.В., Гуреєва С.М., Юр'єва О.О., Лисенко О.С. \& Гой А.М. (2018). Підходи до створення комбінованих твердих лікарських форм. Ліки України плюс, 1 (34), 20-23. 


\section{ПРЕПАРАТЫ В ФОРМЕ ПЕЛЛЕТ, СИСТЕМАТИЗАЦИЯ ИНФОРМАЦИИ О МЕТОДАХ ПРОИЗВОДСТВА, ИССЛЕДОВАНИЯ МИКРОСТРУКТУРЫ И СВОЙСТВ ПЕЛЛЕТ ОМЕПРАЗОЛА}

\author{
Ерхова Анна $^{1}$, Катынская Марина ${ }^{2}$ \\ ${ }^{1}$ Студентка магистратуры, Института \\ биомедицинских технологий, «Открытого \\ международного университета развития \\ человека «Украина», Киев, Украина. \\ ${ }^{2}$ Кафедра фармации Института \\ биомедицинских технологий, «Открытого \\ международного университета развития \\ человека «Украина», Киев, Украина.
}

Аннотация. В статье приведено обзор фармацевтических препаратов в форме пеллет, систематизация информации о методах производства, исследования микроструктуры и свойств пеллет омепразола. Основной целью проведённого исследования является обобщение случаев, когда использование такой формы как пеллеты является наиболее обоснованным, провести обзор лекарственных средств в Украине, содержащих пеллеты, сравнить пеллеты от украиньких производителей (было решено взять пеллеты от корпорации Артериум и Фармак) с зарубежными (в качестве зарубежных производителей, было решено взять производителей Teva и Chemolberica), обобщить современные методы производства пеллет, исследовать доступные пеллеты омепразола от различных производителей, сравнить их характеристики, и обосновать метод, который был использован в производстве. С целью сравнения свойств пеллет от различных производителей было решено исследовать морфологию, плотность, диаметр, среднюю массу пеллет омепразола. Исследовать и сравнить устойчивость кишечнорастворимых пеллет омепразола различных производителей в жидкой среды с различными показателями $\mathrm{pH}$. На основании полученных экспери-

\section{PHARMACEUTICAL PREPARATIONS IN THE FORM OF PELLETS, SYSTEMATIZATION OF INFORMATION ON PRODUCTION METHODS, STUDY OF MICROSTRUCTURE AND PROPERTIES OF OMEPRAZOLE PELLETS}

\author{
Yerkhova Anna ${ }^{1}$, Katynska Maryna ${ }^{2}$ \\ ${ }^{1}$ Master student, Institute of Biomedical \\ Technologies, «Open International \\ University of Human Development \\ «Ukraine». Kyiv, Ukraine. \\ ${ }^{2}$ Pharmacy department, Institute of \\ Biomedical Technologies «Open \\ International University for Human \\ Development «Ukraine». Kyiv, Ukraine.
}

Abstract. The article provides an overview of pharmaceuticals in the form of pellets, systematization of information on production methods, a study of the microstructure and properties of omeprazole pellets. The main purpose of the study is to summarize the cases when the use of such a form as pellets is the most justified, to review drugs in Ukraine containing pellets, to compare pellets from Ukrainian manufacturers (it was decided to take pellets from Arterium Corporation and Farmak) with foreign ones (it was decided to take Teva and ChemoIberica as the foreign manufacturers), to summarize modern methods of pellet production, to study available omeprazole pellets from different manufacturers, compare their properties and justify the method, which was used in production. To compare the properties of pellets from different manufacturers, it was decided to study morphology, density, diameter, the average weight of omeprazole pellets. Investigate and compare the resistance of enteric pellets of omeprazole from different manufacturers to liquid media with different $\mathrm{pH}$ values. Based on the received experimental data to explain the possible reason for differences in properties of the investigated pellets. The method included the study of morphology, density, diameter, average weight. Microscopy and grav- 
ментальных данных объяснить возможную причину различий в свойствах исследуемых пеллет. Методика включала исследования морфологии, плотности, диаметра, средней массы. В работе были использованы микроскопию и гравиметрический анализ. Для исследования устойчивости кишечно пеллет в жидкой среды с различными показателями $\mathrm{pH}$ был использован метод, исследующий прирост содержания влаги (после экспозиции в растворах, имитирующих возможный уровень $\mathrm{pH}$ желудка человека) и потери в массе после высушивания или скорость распада пеллет. Объектом исследования избран пеллет омепразола от производителей корпорации Артериум (Киевмедпрепарат), Фармак, Chemolberica (CI) и Teva. В статье представлены результаты эксперимента, который показал, что все пеллеты имеют резервуарную систему, пеллеты производителей Chemo Iberica, Артериум и Teva были изготовлены методом наслоения для ввода активного фармацевтического ингредиента, а пеллеты от производителя Фармак были выработке с использованием метода прямой пелетизации. Также при исследовании кишечно свойств пеллет были рассчитаны показатели по влагопоглощению и потери в массе после высушивания. Исходя из состава вспомогательных веществ, который представлен в инструкции к препаратам, получается, что в роли функционального полимера при производстве пленочных оболочек в Chemolberica, Teva и Фармак этим полимером выступает метакрилатный сополимер, a у производителя Артериум гипромеллоза фталат. Оба полимеры применяются в пероральной лекарственной форме, как материал для энтерального / кишечно покрытия для таблеток, пеллет или гранул. Результаты проведенного исследования могут быть полезными для дальнейшего совершенствования формул производства препаратов в форме пеллет.

Ключевые слова: кишечнорастворимые пеллеты, метод наслоения активного фармацевтического ингредиента, омепразол, прямая пелетизация. imetric analysis were used in the work. To study the resistance of enteric pellets to liquid media with different $\mathrm{pH}$ values, a method was used that studies the increase in moisture content (after exposure to solutions that mimic the possible $\mathrm{pH}$ level of the human stomach) and weight loss after drying or the rate of decomposition of pellets. The object of the study was omeprazole pellets from the manufacturers Arterium Corporation (Kievmedpreparat), Farmak, ChemoIberica (CI), and Teva. The article presents the results of an experiment that showed that all pellets have a tank system, pellets from ChemoIberica, Arterium, and Teva were made by layering for the introduction of the active pharmaceutical ingredient, and pellets from Farmak were made using direct pelleting. Also in the study of intestinal-soluble properties of pellets were calculated indicators of moisture absorption and weight loss after drying. Based on the composition of excipients, which is presented in the instructions to the drugs, it turns out that the role of functional polymer in the production of film coatings in Chemolberica, Teva, and Farmak this polymer is methacrylate copolymer, and the manufacturer Arterium hypromellose phthalate. Both polymers are used in an oral dosage form as an enteric/enteric coating material for tablets, pellets, or granules. The results of this study may be useful for further improvement of formulas for the production of drugs in the form of pellets.

Keywords: Intestinal soluble pellets, direct pelletization, layering method of active pharmaceutical ingredient, omeprazole. 